\title{
THE COMMITMENT TO ISLAMIC WORK ETHICS AMONG ISLAMIC BANKING EMPLOYEES IN ACEH
}

\author{
Azharsyah Ibrahim ${ }^{1}$ \\ Nor 'Azzah Kamri
}

\begin{abstract}
Ethics play an important role in producing ethical staffs for managing an organization. Ethical staffs perform their duties ethically and offer the best services to the customers. Islamic banking institutions, as Shariah compliant financial institutions, should encourage their employees to implement Islamic work ethics (IWE) to enhance their performance. This article aims to examine the level of IWE commitment among employees of Islamic banks in Aceh. It specifically compares the employee's commitment level on IWE between three categories of Islamic banking in Aceh, namely, the Islamic Commercial Bank (ICB), the Islamic Business Unit (IBU), and the Islamic Rural Bank (IRB). The study employed a quantitative approach in collecting data. The questionnaire surveys were distributed to 268 employees in seven Islamic banks. Of that number, only 208
\end{abstract}

1 Ph.D Candidate, Department of Shariah and Management, Academy of Islamic Studies, University of Malaya, Kuala Lumpur, Malaysia; and Senior Lecturer, Department of Islamic Banking, Ar-Raniry State Islamic University, Banda Aceh, Indonesia, azharsyah@gmail.com

2 Senior Lecturer, Department of Shariah and Management, Academy of Islamic Studies, University of Malaya, Kuala Lumpur, azzah@um.edu.my 
were usable. The results of the findings reveal that employees of the selected Islamic banks in Aceh have very high commitment to implementing IWE in their daily routines. An analysis of the banking categories shows that the employees who work within the IBU have the highest commitment in practicing IWE in their daily jobs, and, statistically, differ from those who work in the other two categories.

Keywords: Islamic work ethics, Islamic banking, Aceh

\section{INTRODUCTION}

The field of Islamic Work Ethics (IWE) has been studied by many researchers in different study settings. Some studies on IWE only focused on fundamental aspects, such as principles and attributes, while others concentrated on certain backgrounds, such as Arab and its related issues. The study by $\mathrm{Ali}^{3}{ }^{3}$ for instance, developed the IWE scale and tested it among 150 Arab students who were studying in major universities in the United States. The result confirmed the scale's reliability and validity to be used in measuring the IWE. In another study, Ali ${ }^{4}$ utilized the scale to examine the IWE and the individualism among 117 managers in Saudi Arabia. He found that the managers in Saudi Arabia were highly committed to the IWE and showed a moderated tendency towards individualism. Further, Yousef ${ }^{5}$ examined the potential mediating role of the IWE between the locus of control, role conflict and role ambiguity using 397 employees in a variety of manufacturing and service organizations in the United Arab Emirates. Using correlation analysis and regression models, the study results showed that the IWE was related to the locus of control and the role of ambiguity. Yousef ${ }^{6}$ also investigated the moderating impact of the IWE on the relationships between organizational commitment and job satisfaction among 425 Muslim employees in several organizations in the United Arab Emirates. The empirical results indicated that the IWE directly affects both

3 Abbas Ali, 'Scaling an Islamic Work Ethic,' The Journal of Social Psychology, 128/5 (1988): 575-583.

4 Abbas J. Ali, 'The Islamic Work Ethic in Arabia,' Journal of Psychology, 126/5 (1992): 507-519.

5 Darwish A. Yousef, 'Organizational Commitment as a Mediator of the Relationship between Islamic Work Ethic and Attitudes toward Organizational Change,' Human Relations, 53/4 (2000): 513-537.

6 Darwish A. Yousef, 'Islamic Work Ethic: A Moderator between Organizational Commitment and Job Satisfaction in A Cross-Cultural Context,' Personnel Review, 30/2 (2001): 152-169. 
organizational commitment and job satisfaction, and that it moderates a positive and significant relationship between the two constructs.

Furthermore, Alhyasat ${ }^{7}$ studied the effect of IWE on the organizational citizenship behaviour in Jordanian press organizations, and singled out the most significant elements of IWE, namely, proficiency, kindness and forgiveness, creativity, fairness and justice. The results were generated from 204 respondents in seven daily newspapers in Jordan. He found that the level of commitment to IWE on the part of workers in the Jordanian press foundations was high. Additionally, Awan and Akram ${ }^{8}$ studied the impact of IWE on innovation capability and the sharing of knowledge, which plays a moderate role in their relationship in public sector organizations in Pakistan. Based on 102 respondents, the study showed that there was a significantly positive relationship between IWE and innovation capability. When knowledge sharing was installed as a moderator between their relationships, the result was also positively significant. Likewise, Kumar and Che Rose ${ }^{9}$ investigated the influence of IWE on innovation capability in the Malaysian public sector. The findings showed support for the relationship between the variables. IWE was found to be significant with moderate correlation and a positive relationship to the innovation capability scale. Similarly, Rahman, Muhamad, and Othman ${ }^{10}$ investigated the relationship between IWE and organizational commitment among 227 employees in a local bank in Malaysia. The result shows that IWE has a close correlation with organizational commitment.

Notwithstanding the fact that the studies have interestingly discussed IWE in various contexts, the role of IWE in the Islamic Banking Institutions (IBIs) context has not received adequate attention. The implementation of IWE in the IBIs is very significant as some features of IWE have empirically proved their ability to boost the performance of organizations including IBIs. For example,

7 Khaled M. K. Alhyasat, 'The Role of Islamic Work Ethics in Developing Organizational Citizenship Behavior at the Jordanian Press Foundations,' Journal of Islamic Marketing, 3/2 (2012): 139-154.

8 Khurram Zafar Awan \& Mehwish Akram, 'The Relationship Between Islamic Work Ethics and Innovation Capability and Knowledge Sharing Plays Moderation Role,' International Journal of Economics and Management Sciences, 1/8 (2012): 34-48.

9 Naresh Kumar \& Raduan Che Rose, 'Examining the Link between Islamic Work Ethic and Innovation Capability,' Journal of Management Development, 29/1 (2010): 79-93.

10 Nik Mu’tasim Ab. Rahman, Nordin Muhamad \& Abdullah Sanusi Othman, 'The Relationship Between Islamic Work Ethics and Organizational Commitment: A Case Analysis,' Malaysian Management Review, 41/1 (2008): 79-89. 
in a study in the Pakistani telecom industry, Abbasi, Rehman, and Bibi, ${ }^{11}$ found that IWE has great potential to improve the business performance of an organization. Additionally, the work of Abbasi, Mir, and Hussain ${ }^{12}$ supported the argument that adopting the IWE values in a business organization would eventually boost organizational performance. Naser, Jamal, and Al-Khatib ${ }^{13}$ found that customer satisfaction (as one of the performance factors) in IBIs was closely linked to the way the bank observes Islamic principles in their services. In addition, the customers trusted the bank as regards their money and in its ability to satisfy religious concerns. Therefore, Islamic banks that value the critical importance of long-term relationships with their customers, should achieve an environment in which the potential for unethical behaviour is at a minimum.

In the context of Aceh, the implementation of IWE in organizations including the IBIs is very relevant as Aceh is the only province in Indonesia that is legally allowed to implement Shariah law in all aspects of life including the banking sector based on the enactment of the Indonesian Act No. 44/1999, Act No. 18/2011, and Act No. 11/2006. The current administration of Aceh province considers this factor to be significant in boosting people's economy. At the moment, the government of Aceh is developing the 'grand design of Shariah law' and the 'roadmap of Islamic economics in Aceh' that govern many aspects of life including the banking sector. Consequently, every business activity both individual and of a corporate nature, must be based on Islamic principles. Thus, any corporation that intends to operate in Aceh should ensure its operations are in accordance with Shariah law. The practices of Shariah law must be adopted by every corporation in developing a good relationship with the community and stakeholders. For any breach of the law in its relationship to the community, a company will face legal action or social punishment from the community. As the banking industry plays an important role in boosting people's economy in Aceh, considering Islamic ethical values in its operations is very important.

11 Abdus Sattar Abbasi, Kashif Ur Rehman \& Amna Bibi, 'Islamic Work Ethics: How it Affcets Business Performance,' Actual Problem of Economics, 126/12 (2011): 312-322.

12 Abdus Sattar Abbasi, Ghulam Mustafa Mir \& Muzammil Hussain, 'Islamic Work Ethics: How They Affect Organizational Learning, Innovation and Performance,' Actual Problem of Economics, 12 (2012): 471-480.

13 Kamal Naser, Ahmad Jamal \& Khalid al-Khatib, 'Islamic Banking: a Study of Customer Satisfaction and Preferences in Jordan,' International Journal of Bank Marketing, 17/3 (1999): 135-151. 
Among the many factors, the employee is one of the most significant that influences an Islamic bank's operations. As stated by Hassan, Chachi and Latiff, ${ }^{14}$ the employee, especially the Customer Relationship Advisor (CRA), is the most visible representative of an Islamic bank in the eyes of its customers. Islamic banks, and, more specifically, their CRAs need to be perceived by their customers as being Islamic. Thus, the employees' commitment to Islamic ethical values in their daily jobs is important to ensure the customers' trust and maintain their loyalties. For that reason, this study is aimed at examining the level of IWE commitment among employees of Islamic banking in Aceh.

\section{ISLAMIC WORK ETHICS}

In understanding the work ethics concept from various perspectives including the Islamic perspective, one should first understand the term 'ethics' as it is a common term in reflecting human behaviour. ${ }^{15}$ In Islam, the term 'ethics' designates several terms denoting the concept of morals. There are al-khāyr (goodness), al-birr (righteousness), al-qist (equity), al-haq (truth and right), al'adl (justice), al-ma 'rüf (known and approved) and al-taqwā (piety). Among them all, the most common term that refers to ethics is akhlāq. Meanwhile, work in Islam is distinguished from other beliefs. Islam views work as an integral part of worship. Within this view, every Muslim will envision his work in a twofold manner: as a source of financial support and achieving good worldly life (al-falāh fi al-dunyā), as well as a means of serving Allah and preparing for the success of afterlife (al-falāh fì al-äkhirah). More comprehensively, work in Islam is not only to achieve material and human physical pleasure but it is also a form of human engagement and cooperation (al-ta' 'âwun), an act of worship ( $a l$ - 'ibādah), an act of kindness towards others (al-ihsān), the execution of responsibilities and accountabilities (al-amānah), the security of self-dignity (hifz al-murü'ah) and as a part of reliance towards God (altawakkal). For these reasons, Islam holds work in the highest regard, to the extent of considering it as an articulation of one's faith, thus accentuating its vital role in life. Thus, IWE is defined as performing positive actions with good intentions as a way of getting blessings from Allah SWT and to benefit society and oneself.

14 Abul Hassan, Abdelkader Chachi \& Salma Abdul Latiff, 'Islamic Marketing Ethics and Its Impact on Customer Satisfaction in the Islamic Banking Industry,' J.KAU: Islamic Econ, 21/1 (2008): 23-40.

15 Sharifah Hayaati Ismail al-Qudsy, 'Values and Ethics Towards Quality Public Delivery System of Malaysia: An Islamic Perspective,' Shariah Journal, 15/2 (2007): 25-43. 


\section{Principles and Dimensions of IWE}

Based on the works of Naqvi, ${ }^{16}$ Beekun, ${ }^{17}$ Dusuki, ${ }^{18}$ and Yusuf, ${ }^{19}$ the researchers concluded that in conducting work activities within the Islamic ethical framework, five principles need to be followed, namely tawhìd, khiläfah, 'adl, $i k h t i y \bar{a} r$ and fard. These principles are not stand-alone principles, but they are related to each other. They generate eight dimensions of IWE, namely religiousness, effort, competition, work obligation, quality, collectivity, equality and benefit. Specifically, it will promote the act of religiousness such as taqwā or ihsān, develop conscience (the sense of right or wrong), and so on. It will also observe effort as an obligation to achieve needs, and view competition from different and positive angles. In addition, the conformity to the principles will also affect the way people conduct their work obligations. Consequently, it will boost work quality and promote collectivity and equality in the workplace. In the end, it will have the very significant effect of benefitting both oneself and society. Conforming to these dimensions will stimulate positive actions in the workplace and create a hard-working employee, honest, patient, responsible, creative, sincere, decent, diligent, and with many other positive values. Specifically, the values of IWE will optimize work performance, perform work as worship, forge harmonious relationships in the workplace, develop mutual trust among business partners, enhance organizational commitment, and promote teamwork and collectiveness. ${ }^{20}$

\section{ISLAMIC BANKING IN ACEH}

The banking system in Aceh, including its Islamic banking system, is an integral part of the Indonesian banking system as it stands in an integral law system. Thus, the discussion on Islamic banking in Aceh cannot be separated from the discussion of the Indonesian Islamic Banking system.

\footnotetext{
16 Syed Nawab Haider Naqvi, Ethics and Economics: An Islamic Synthesis (Leicester, UK: Islamic Foundation, 1981), 176.

17 Rafik Issa Beekun, Islamic Business Ethics.

18 Asyraf Wajdi Dusuki \& Humayon Dar, 'Stakeholders' Perceptions of Corporate Social Responsibility of Islamic Banks: Evidence from Malaysian Economy' (Paper presented at the International Conference on Islamic Economics and Finance, Jeddah, 2007), 389-417.

19 Muhammad Yasir Yusuf, 'Tanggung Jawab Sosial Korporat pada Institusi Perbankan Islam di Aceh: Analisis Kriteria dan Persepsi' (Doctoral Thesis, Universiti Sains Malaysia, 2012), 471.

20 Nor Azzah Kamri, Siti Fairuz Ramlan \& Azharsyah Ibrahim, 'Qur'anic Work Ethics,' Journal of Usuluddin, 40 (July-December 2014): 135-172.
} 


\section{Indonesian Islamic Banking System}

According to the Indonesian Act for Islamic Banking No. 21/2008, an Islamic bank is 'a bank conducting business based on the Sharia Principles consisting of Islamic Commercial Bank and Islamic Rural Bank.' Meanwhile, Islamic banking is 'all matters concerning Islamic Bank and the Islamic Business Unit, including institution, business operation, and means and process in the implementation of its business operation.' ${ }^{21}$ Further, the Act also divided the type of Islamic banking in Indonesia into three categories, namely, Bank Umum Syariah (Islamic Commercial Bank), Unit Usaha Syariah (Islamic Business Unit), Bank Pembiayaan Rakyat Syariah (Islamic Rural Bank). According to the Act in chapter I article 1:

(1) Islamic Commercial Bank is an Islamic bank providing services in the transaction of payments; (2) Islamic Rural Bank is an Islamic bank which does not provide services in the transaction of payments; (3) Islamic Business Unit is a working unit of the Conventional Commercial Bank head office functioning as head office of offices or units conducting business activities based on the Sharia principle, or working unit in a branch office of a Bank located overseas conducting conventional business activities functioning as a head office of sub-Islamic branches and/or Islamic unit. $^{22}$

\section{The Growth of Islamic Banking in Indonesia}

The volume of the Islamic banking industry in Indonesia, particularly Islamic Commercial Banks and Islamic Business Units, is experiencing unprecedented growth. By August 2014, the total assets of the industry rose to IDR244.197 trillion from IDR242.276 trillion in 2013. ${ }^{23}$ In addition, the assets of Islamic Rural Banks also experienced a significant growth from IDR5.684 trillion to IDR6.082 trillion in the same period. Thus, the total assets of Islamic banking by August 2014 reached IDR248.358 trillion and it is projected using to grow between $36-58$ percent (pessimistic-optimistic) in $2015 .{ }^{24}$

\footnotetext{
$21 \quad$ Indonesian Act of Islamic Banking 1.

22 Indonesian Act of Islamic Banking 1.

23 Otoritas Jasa Keuangan, Statistik Perbankan Syariah (Islamic Banking Statistic), August 2014 ed. (Jakarta: OJK, October 2014).

$24 \quad$ RM1 $=$ IDR3,527.56 on June 2015.
} 
In terms of quantity, the number of Islamic banks has remained the same in the last couple of years, but the number of offices had increased significantly by 2014. According to Otoritas Jasa Keuangan (OJK), the Indonesian Financial Service Authority, as per August 2014, the total number of Islamic banking offices had reached 3,000 offices. ${ }^{25}$

\section{Ethical Issues in Islamic Banking}

However, in general, the rapid growth of Islamic banking is viewed as an overwhelming convergence of IBIs with Conventional Banking Institutions (CBIs) in terms of operations and products. IBIs appear to have compromised their 'moral economy' related objectives and outcomes by locating themselves within neo-classical economies. According to Asutay, ${ }^{26}$ the paradigm shift from the Islamic Moral Economy (IME) to the Islamic finance industry, and, in particular, the adoption of the commercial institutionalization of this industry globally since the mid-1970s represents an important divergence. The evidence on the current practice of most Islamic banks worldwide including Indonesia suggests that the majority of financing operations is not based on equity; rather, Islamic banks have consistently favoured the use of debt-based modes of financing. Commercial IBIs totally ignore developmental efforts; their main aim is entirely profit maximization rather than ethical profit. Consequently, when the global economic and monetary crisis occurred in 2007-2008, the IBIs were also affected. ${ }^{27}$ Specifically, defects in certain Islamic financial transactions have also been witnessed in the last couple of years. In Indonesia, a fraudulent case involving individuals in an Islamic Business Unit of the Regional Development Bank of Central Java (Bank BPD Jawa Tengah), for instance, was reported in August 2011. The fraud lingered at around IDR24 billion recognized as a loss for the financial year of $2011 .^{28}$

25 Otoritas Jasa Keuangan, Statistik Perbankan Syariah (Islamic Banking Statistic).

26 Mehmet Asutay, 'The Socio-Ethical Failure in Islamic Banking and Finance' (IIBI Lecturer Series, Institute of Islamic Banking and Insurance, London, October 2011), www.newhorizon-islamicbanking.com/index.cfm?section=lectures\&id=1 $1252 \&$ action $=$ view.

27 Mohammad Taqiuddin Mohamad, Joni Tamkin Borhan \& Ahmad Azam Sulaiman@Mohamad, 'Krisis Kewangan Global: Kestabilan dan Karakteristik Unik Perbankan Islam,' Shariah Journal, 22/1 (2014): 57-86.

28 Ainur Rahman, 'Menghapus Nila Setitik di Bank Syariah,' Majalah Stabilitas, http://www.stabilitas.co.id/view_articles.php?article_id=231\&article_ type $=0 \&$ article_category=2., accessed on 6 April 2012. 
This kind of case creates suspicion amongst unconvinced Muslims and other critical outsiders who observe that, in reality, Islamic banks are no different from conventional banks since the net result of Islamic banking operations is the same as that of conventional banking. ${ }^{29}$ Despite the fact that cases of financial scandals involving IBIs are rare, this case implies that IBIs are socially-constructed reality not a divine revelation, and, therefore, are prone to the fallibility of all things human ${ }^{30}$ as well as the chances of failure between theory and practice. ${ }^{31}$

The Indonesian Financial Service Authority or Otoritas Jasa Keuangan $(\mathrm{OJK})$, as the new sole regulator ${ }^{32}$ of financial services in Indonesia, has set a blueprint for developing the banking system, including Islamic banking, to ensure the stability of the banking sector and thus improve the country's economy. ${ }^{33}$ In line with that, the Central Bank of Indonesia (BI) has urged all banks operating in Indonesia to implement five ethical values within the concept of Good Corporate Governance (GCG), namely transparency, accountability, responsibility, professionalism, and fairness. ${ }^{34}$ For Islamic banking itself, the initiative from IWE has been incorporated into its corporate culture. Bank Muamalat Indonesia (BMI), for instance, has specifically set seven ethical behaviours that must be accounted for and requires all employees to make the oral and written oaths to work accordingly. Similar actions (but with a different approach) have also been taken by other Islamic banks, such as Bank Syariah Mandiri (BSM), Bank Negara Indonesia Syariah (BNIS), Bank Rakyat Indonesia Syariah (BRIS), and other Islamic banks. Therefore, it is interesting to investigate the practice of IWE within the Islamic banking in Indonesia as these principles are closely related to the Islamic work ethical values.

29 Asyraf W. Dusuki, 'The Ideal of Islamic Banking: A Survey of Stakeholders' Perception,' Review of Islamic Economics, 11, no. special (2007): 29-52.

30 Mehmet Asutay, 'The Socio-Ethical Failure in Islamic Banking and Finance.'

31 M. Adli Musa, 'Islamic Business Ethics \& Finance: An Exploratory Study of Islamic Banks in Malaysia' (Paper presented at the 8th International Conference on Islamic Economics, Doha, Qatar, 2011).

32 Effective per 1 January 2013, the Otoritas Jasa Keuangan (OJK) has been appointed to regulate all financial services in Indonesia. All related data from previous regulator, Bank Indonesia, was shared to the new regulator. For more information, please refer to: http://www.ojk.go.id/en/

33 'Sharia Bank,' Otoritas Jasa Keuangan Indonesia, http://www.ojk.go.id/en/ sharia-bank., accessed on 27 November 2014.

34 Bank of Indonesia's Circular Letter No. 15/063A/OPS dated 30 September 2013 on Goods and Services Procurement Implementation. 


\section{METHODOLOGY}

This study employed a quantitative approach using questionnaire surveys as the method for collecting data. The questionnaire surveys were prepared in two formats, printed and online. The latter was created using a 'Form' application freely available from Google Drive. ${ }^{35}$ The surveys were delivered in various ways depending on necessity, availability and convenience. Most of the surveys were handed over to their respective banks to be distributed (drop-off survey), while others were delivered using Internet-based services, i.e. email, Facebook, and Twitter, by providing a link to the online survey.

The IWE was measured using a self-developed instrument consisting of 47 items within eight previously mentioned dimensions. Examples of items for each dimension included: 'I work for an Islamic bank because its products are Shariah compliant' (religiousness), 'In working, I always strive for the best result' (effort), 'I believe that competition is able to improve the quality of work' (competition), 'I will do my best to fulfil contracts with customers' (work obligation), 'For me, creative work is a source of happiness and accomplishment' (quality), 'For me, collective success is more important than personal success' (collectivity), 'I respect each customer regardless of his/ her social background' (equality), 'One should consider community affairs in his/her work' (benefit). The instrument was tested in a pilot study using 50 respondents. The results of the pilot study showed that Cronbach's alpha reliability statistic test for all 47 items of IWE was 0.935 , thus indicating that all items were very strong for measuring the IWE in a real survey. It was also supported by the item-total correlational analysis using Pearson Correlation, which showed that all items were valid and significant. ${ }^{36}$

The questionnaires were distributed to all employees (268 people) in the seven offices of seven different Islamic banks located in Banda Aceh from three categories of Islamic banking in Indonesia, as shown in Table 1. A total of 225 surveys were collected, which was equivalent to 83.95 percent of the initial response rate. After careful review, 17 surveys were unqualified due to incomplete responses to more than three items in each construct's list of questions, and thus rejected. This resulted in 208 usable responses.

35 For more information regarding this application, please refer to: https://www. google.com/intl/en/drive/

36 Azharsyah Ibrahim \& Nor 'Azzah Kamri, 'Measuring the Islamic Work Ethics: An Alternative Approach,' in Islamic Perspective on Management: Contemporary Issues, ed. Nor 'Azzah Kamri, Azian Madun \& Suhaili Sarif (Kuala Lumpur: YaPEIM Management Academy \& Dept. of Shariah and Management, Acad. of Islamic Studies, University of Malaya, 2013), 135-163. 
Table 1: Sample of Bank for Questionnaire Distribution

\begin{tabular}{lll}
\hline \multicolumn{1}{c}{ Bank's Category } & & \multicolumn{1}{c}{ Name of Bank } \\
\hline & 1. & Bank Muamalat Indonesia (BMI) \\
Islamic Commercial & 2. & Bank Syariah Mandiri (BSM) \\
Bank (ICB) & $\begin{array}{l}\text { 3. } \\
\text { 4. }\end{array}$ & Bank Rakyat Indonesia Syariah (BRIS) \\
& 5ank Negara Indonesia Syariah (BNIS) \\
\hline $\begin{array}{l}\text { Islamic Business } \\
\text { Unit (IBU) }\end{array}$ & 6. & Bank Aceh Syariah (BAS) \\
\hline & $\begin{array}{l}\text { Wakilah (BHW) } \\
\text { Islamic Rural Bank } \\
\text { (IRB) }\end{array}$ & $\begin{array}{l}\text { Bank Pembiayaan Rakyat Syariah Hareukat } \\
\text { (BHR) }\end{array}$ \\
\hline
\end{tabular}

Source: Field Data

\section{RESULTS AND DISCUSSION}

The level of commitment towards IWE for the employees of Islamic banking in Aceh is measured through the total mean $(M)$ score, which is gathered from eight dimensions of IWE, namely religiousness, effort, competition, work obligation, quality, collectivity, equality, and benefit. These dimensions function as the tool of analysis to determine the commitment of the Islamic banking's employees in Aceh to adopt the Islamic ethical values in working. The measurement is also supported by the value of standard deviation $(S D)$. The $S D$ measures the amount of variation or dispersion from the average. A low standard deviation indicates that the data points tend to be very close to the mean (also called expected value); a high standard deviation indicates that the data points are spread over a large range of values. ${ }^{37}$

The measurement of perception towards IWE was analysed using six score scales ranging from score 1, which represents the feeling of 'strongly disagree', to score 6, which represents the feeling of 'strongly agree'. Based on these scales, the 'mean' score for each item was identified. Further, the 'mean' score was simplified and classified into three categories (half of the scale), as shown in Table 2.

37 J Martin Bland \& Douglas G Altman, 'Statistics Notes: Measurement Error,' Bmj, 312/21 (1996): 1654. 
Table 2: Classification of Mean Value

\begin{tabular}{ccc}
\hline No. & Mean Classification & Category \\
\hline 1. & 1.00 to 2.60 & Low \\
2. & 2.61 to 4.20 & Medium \\
3. & 4.21 to 6.00 & High \\
\hline
\end{tabular}

Source: Adapted from Husein Umar, Metode Penelitian untuk Skripsi dan Tesis Bisnis (Jakarta: RajaGrafindo Persada, 2007), 335.

The findings indicated that all dimensions of IWE were included in a 'high' category within the range 4.21 to 6.00 . Of the eight dimensions, seven dimensions received a score above 5.00, while one dimension (competition) slipped below 5.00. The breakdown of each dimension revealed that the collectivity dimension received 5.47 of mean value, which was the highest mean among all the dimensions. This indicated that the employees reflected a high degree of commitment to collectivity and contributed significantly to the overall IWE commitment. All the items within this dimension had consistently received mean scores above 5.42. For most of the employees, a good relationship with colleagues was very important as it stimulated collectivity through cooperation and teamwork. In addition, the employees were willing to consult their colleagues or supervisor and help each other to solve work problems. They believed that collective success was more important than personal success.

From the perspective of Islamic banks, the results were in line with their IWE initiatives. The collectivity components were considered to be one of the guidance factors for the employees of Islamic banks in performing their jobs. BNIS, ${ }^{38}$ for instance, placed collectivity as one of their corporate cultures. Under this culture, every individual in this bank is required to care and have courage in giving as well as taking constructive feedback, establishing professional synergy, sharing knowledge with others, and understanding the correlation in working processes. Meanwhile, $\mathrm{BMI}^{39}$ considers human capital and its teamwork as important aspects in running their business. A similar value was also upheld by BAS, ${ }^{40}$ which placed 'partnership and trust' on their

38 BNI Syariah, Annual Report 2012: Reliable Banking Partner (Jakarta: BNI Syariah, 2012), 114.

39 Bank Muamalat Indonesia, Annual Report 2012: The Great Leap Forward (Jakarta: Bank Muamalat Indonesia, 2012), 532.

40 Bank Aceh, Annual Report 2012: Strategic Transformation, Building and Strengthening Foundation of Bank Business Growth (Banda Aceh: Bank Aceh Syariah, 2012), 282. 
tagline. Related values with different wordings were also upheld by other selected Islamic banks. Thus, every individual in the banks is guided by a set of values as the guideline for establishing their attitude.

Furthermore, the dimension of religiousness scored 5.44, which was the second highest among the dimensions. This implies that employees of Islamic banking in Aceh consider all factors within this dimension to be significant in performing their daily jobs. It can be observed by various indicators. Firstly, as Muslims, most employees perform their worship regularly. This indicates that they are able to conduct such activities (performing șalāt, hajj, fasting during the holy month of Ramaḍan, paying their zakāh, and so forth) everywhere including at their workplace as the facilities for that are readily available. Secondly, the employees highly believed that work is one of the ways of worshipping Allah in accordance with the Islamic teachings. Thirdly, the employees considered that work should not only be derived from its output, but also from its accompanying intention, thus any non-halal (unlawful) work (e.g. gambling, prostitution, drug trafficking, deceiving, extortion, hoarding, monopoly) is condemned even though it results in a significant accumulation of wealth for those who undertake it.

Additionally, the high commitment towards the IWE values was also reflected through the dimension of equality $(M=5.42, S D=0.61)$. This reveals that the employees of Islamic banking in Aceh considered respect for customers as very important and thus treated them fairly regardless of their social background. This kind of behaviour was derived from the treatment the employees received from their employer and their own beliefs that humility at work is a virtue. These scores indicated that the employees of Islamic banking in Aceh were fully aware of the equality dimension as one of the Islamic values at work. In general, it contributed significantly to increase the employees' commitment towards IWE.

For the dimension of quality, the overall mean score was 5.40. This result provided information that most respondents were highly committed to performing their daily jobs with utmost quality in accordance with IWE values. For most of the Islamic banking employees, quality was something important to perform work professionally. Thus, in order to do that, they were always eager to learn something new, work carefully, and considered creative work as a source of happiness and accomplishment.

In addition, the mean value for the dimension of 'work obligation' is included in a high category $(M=5.31, S D=0.57)$. The high level of employees' commitment towards IWE in this dimension can be observed through the mean scores of each item within this dimension. In the banking industry, financial information is a vital object. Thus, keeping this information as safe as possible 
is very important. For the employees of the selected Islamic banks in Aceh, this condition was fully understood and thus acted upon. In order to do that, the respondents were aware that honesty in working was a prerequisite. Other indications that showed that respondents had high level commitment towards IWE within the work obligation dimension were their punctuality, dignity, and discipline.

Similarly, the dimension of effort also scored high $(M=5.26, S D=0.57)$ in the tests that indicated the significant contribution of this dimension to the employees' IWE commitment. Within this dimension, the employees of Islamic banking stated that they had always striven for the best results by performing their job to the best of their ability and avoiding laziness. The results of this dimension show that the employees of the selected Islamic banks in Aceh were taking their jobs seriously. The effort factors proved that employees of Islamic banking in Aceh have high level commitment to the IWE as they perform work in accordance with the Islamic teachings.

Likewise, the dimension of benefit has also shown that employees of IBIs in Aceh have a high social feeling towards society $(M=5.23, S D=0.60)$. This can be observed from their answers to statements given to express their personal feelings. For most of them, having a high income means a significant contribution to society via some form of charity, such as zakāh, infāq and sadaqah. It was likely that work was a way to get ahead in their lives because it gave them a chance to be independent, foster their personal growth and their social relationships. Thus, doing good work not only benefitted themselves but also the surrounding society.

Lastly, the dimension of competition where the overall items received a mean value of 4.85 . Based on the classification mentioned above, it was also categorized as high. Looking at the items closely revealed that most employees believed that, in general, competition is able to improve quality of work. The respondents affirmed that competition among Islamic banking at the institutional level was fair while the internal competition at their workplaces was also fair. Among other IWE dimensions, this was the only dimension that had a mean below 5.00 and thus was the lowest among them. This implies that although, overall, it was categorized 'high', most probably there were some items within this dimension that required more attention. Thus, a closer analysis of the items exposed that the 'mean' for item 16 was the lowest among all the items in the questionnaire (ranked 47 of 47 items) and contributed to lowering the overall score of the competition dimension. Interestingly, the statement in item 16 was presented in a negative format. It seemed that most respondents had mistakenly identified the statement, which was placed among 
positive statements, and thus failed to provide a proper response. The results were generated from a very reliable mean value as it was showed by the value of standard deviation $(S D)$. The $S D$ indicated that the majority of data points were positioned extremely close to the mean. The closer the $S D$ is to 0 , the more reliable is the mean. The summary of the above discussion from the highest to lowest $M$ values and the $S D$ is presented in Table 3.

Table 3: Summary of IWE Dimension Descriptive Statistics

\begin{tabular}{lccc}
\hline IWE Dimension & Mean & Std Deviation & Category \\
\hline Collectivity & 5.47 & 0.59 & High \\
Religiousness & 5.44 & 0.52 & High \\
Equality & 5.42 & 0.61 & High \\
Quality & 5.40 & 0.62 & High \\
Work Obligation & 5.31 & 0.57 & High \\
Effort & 5.26 & 0.57 & High \\
Benefit & 5.23 & 0.60 & High \\
Competition & 4.85 & 0.81 & High \\
\hline Total Average & $\mathbf{5 . 3 0}$ & $\mathbf{0 . 6 1}$ & High \\
\hline
\end{tabular}

Source: SPSS Output.

The above-mentioned facts show that the employees of Islamic banking in Aceh were fully aware and thus had very high commitment to the Islamic values in their daily jobs, as is reflected in their responses to the given questionnaires. The positive commitment to IWE might provide several advantages for both the employees and the banks as it encourages hard work, commitment and dedication to work, work creativity, cooperation and fair competitiveness in the workplace. This result is consistent with various research, such as Ali, ${ }^{41} \mathrm{Ali}$ and Al-Shakhis, ${ }^{42}$ Ali and Azim, ${ }^{43}$ Yousef, ${ }^{44}$ and Marri et al. ${ }^{45}$ It must be noted, however, that these aforementioned studies were carried out using national

${ }^{41}$ Abbas Ali, 'Scaling an Islamic Work Ethic,' 575-583; Abbas J. Ali, 'The Islamic Work Ethic in Arabia,' 507-519.

42 Abbas Ali \& Mohammed Al-Shakhis, 'Managerial Beliefs About Work in Two Arab States,' Organization Studies, 10/2 (1989): 169-186.

43 Abbas J. Ali and Ahmed A. Azim, 'Islamic Work Ethic and Organization in Development' (Paper presented at the $23^{\text {rd }}$ International Congress of Applied Psychology, Madrid, Spain, 1994).

44 Darwish A. Yousef, 'Islamic Work Ethic,' 152-169.

45 Muhammad Yousuf Khan Marri et al., 'Measuring Islamic Work Ethics and its Consequences on Organizational Commitment and Turnover Intention an Empirical Study at Public Sector of Pakistan,' International Journal of Management Sciences and Business Research, 2/2 (2013): 37-49. 
culture - in this case Arab and Pakistani - and the measurement items were developed based on this viewpoint. The results of these studies were generated from the general opinion of respondents, not from their application. Meanwhile, this current study was conducted in a very different atmosphere using the local culture approach (i.e. the differences among employees in valuing the work, customers, employers, colleagues, etc.). The items were developed based on the implementation in respondents' daily activities. Based on this, it is possible to interpret that the results of this study is the reflection of most respondents' manners in their daily jobs at the selected Islamic banks in Aceh.

An analysis of the three different categories of Islamic banking showed that the employees' commitment to IWE was also generally high, as shown in Table 4. This indicates that the employees of Islamic banking in Aceh from all categories have practiced or at least have a willingness to practice IWE, and incorporate the Islamic ethical values in their daily job activities.

Table 4: IWE Commitment Level based on Bank's Category

\begin{tabular}{lccc}
\hline \multirow{2}{*}{ Items } & \multicolumn{3}{c}{ Mean } \\
\cline { 2 - 4 } & $\begin{array}{c}\text { ICB* } \\
(\mathbf{n = 9 7 )}\end{array}$ & $\begin{array}{c}\text { IBU* } \\
(\mathbf{n = 6 3 )}\end{array}$ & $\begin{array}{c}\text { IRB* } \\
\mathbf{( n = 4 8 )}\end{array}$ \\
\hline Religiousness & 5.47 & 5.56 & 5.21 \\
Effort & 5.16 & 5.45 & 5.20 \\
Competition & 4.78 & 4.97 & 4.82 \\
Work Obligation & 5.23 & 5.49 & 5.25 \\
Quality & 5.37 & 5.56 & 5.28 \\
Collectivity & 5.45 & 5.64 & 5.30 \\
Equality & 5.39 & 5.56 & 5.30 \\
Benefit & 5.18 & 5.34 & 5.19 \\
\hline Total Means & $\mathbf{5 . 2 5}$ & $\mathbf{5 . 4 5}$ & $\mathbf{5 . 1 9}$ \\
\hline Source: Adapted from SPSS Output & & & \\
* ICB = Islamic Commercial Bank & & & \\
IBU = Islamic Business Unit & & & \\
IRB = Islamic Rural Bank & & &
\end{tabular}

Analysing the table closely revealed that the levels of IWE commitment among employees within the categories are different. The employees of IBU have the highest commitment to IWE in all tested dimensions $(M=5.45)$, followed by ICB $(M=5.25)$, and IRB $(M=5.19)$.

To provide more convincing results, a one-way analysis of variance (ANOVA) was run to determine if there were statistically significant differences 
in commitment to IWE between the employees of ICB, IBU, and IRB. The result is that the $F$ value (4.672) is greater than $F$ table $(3.040)^{46}$ and $p$ value is 0.01 , which is less than the significance level of 0.05 , as displayed in Table 5. Therefore, this indicates that the IWE commitment between the employees who work at ICB, IBU, and IRB in Aceh is significantly different.

Table 5: One-way ANOVA based on Bank Category

\begin{tabular}{lrrrcc}
\hline & Sum of Squares & df & Mean Square & F & Sig \\
\hline Between Groups & 6350.083 & 2 & 3175.041 & 4.672 & 0.01 \\
Within Groups & 139321.185 & 205 & 679.616 & & \\
\hline Total & $\mathbf{1 4 5 6 7 1 . 2 6 8}$ & $\mathbf{2 0 7}$ & & & \\
\hline
\end{tabular}

Source: SPSS Output

To know which of the specific categories differed, Tukey post-hoc tests were undertaken. If the $p$ value is greater than $0.05(p>0.05)$, there is no statistically significant difference between the groups, while if the $p$ value is less than or equal to $0.05(p \leq 0.05)$, there is a statistical difference in the three groups of Islamic banks. As presented in Table 6, it is revealed that there are significant differences in IWE commitment between the employees who work within the IBU and ICB ( $p=0.033)$, as well as between the IBU and IRB ( $p$ $=0.017)$. However, there are no significant differences between the ICB and $\operatorname{IRB}(p=0.769)$.

Table 6: Tukey Post-hoc Test for Bank Category

\begin{tabular}{|c|c|c|c|c|c|c|}
\hline \multirow{2}{*}{\multicolumn{2}{|c|}{ Bank }} & \multirow{3}{*}{$\begin{array}{c}\text { Mean } \\
\text { Difference }\end{array}$} & \multirow{3}{*}{ Std Error } & \multirow{3}{*}{ Sig } & \multicolumn{2}{|c|}{ 95\% Confidence Interval } \\
\hline & & & & & Lower & Upper \\
\hline & & & & & Bound & Bound \\
\hline \multirow{2}{*}{ ICB } & IBU & $-10.66235^{*}$ & 4.21828 & 0.033 & -20.6211 & -0.7036 \\
\hline & IRB & 3.17620 & 4.60054 & 0.769 & -7.6851 & 14.0375 \\
\hline \multirow{2}{*}{ IBU } & ICB & $10.66235^{*}$ & 4.21828 & 0.033 & 0.7036 & 20.6211 \\
\hline & IRB & $13.83855^{*}$ & 4.99462 & 0.017 & 2.0469 & 25.6302 \\
\hline \multirow{2}{*}{ IRB } & ICB & -3.17620 & 4.60054 & 0.769 & -14.0375 & 7.6851 \\
\hline & IBU & $-13.83855^{*}$ & 4.99462 & 0.017 & -25.6302 & -2.0469 \\
\hline
\end{tabular}

Source: SPSS Output

* The mean difference is significant at the 0.05 level.

The ANOVA and Tukey Post-hoc tests, as displayed in Tables 5 and 6, confirmed that the employees who work in the IBU category in Aceh have the

46 Please refer to $F$-table at the 0.05 significance level: df1 (Number of Groups [3]$1=2$ ), and df2 (No. of Respondents [208] - Groups [3] = 205). Thus, the value of $F$-table is 3.040 . 
highest commitment in practicing IWE in their daily jobs, which statistically differs with those who work in other categories, especially the ICB. This result was a little surprising since the basis of IBU and its employees are from conventional banks, which are less concerned about religious matters. One possible reason is because the sample bank selected for the IBU category is Bank Aceh Syariah (BAS), an IBU of Bank Aceh. As Bank Aceh is owned by the provincial government of Aceh, most of its employees come from Aceh. In Indonesia, Aceh is known as Serambi Mekkah (the Veranda of Mecca) which reflects the religiosity of its people. Thus, the people of Aceh have commonly lived in accordance with Islamic teachings in almost all aspects of life for a very long time.

Another possible reason is related to the spin-off initiative to separate BAS from its conventional parent company to become a full-fledged Islamic bank. The preparation for this plan was started in the last couple of years. The most visible action is the recruitment of new employees to be stationed in the BAS throughout the branches. The newly recruited employees for this IBU were graduates of Islamic banking schools of various universities across the country, particularly Aceh. As is commonly known, the curriculum of these particular schools has embedded Islamic values in its core knowledge. In considering this factor, the result is understandable.

\section{CONCLUSION}

The results of data analysis revealed that, in general, the employees of the selected Islamic banks in Aceh have a very high commitment to implement the IWE values in their daily routines. These results were generated by the analyses of mean values and standard deviation of each item from the questionnaire survey, which was measured using a six-value scale ranging from 1 (lowest commitment) to 6 (highest commitment). The dimension of collectivity shows the highest mean value, while the competition dimension shows the lowest mean value among them. The overall mean value was high. Specifically, an analysis of the bank categories showed the differences in the way the employees were committed to it, especially between those who worked within IBU and ICB, and between IBU and IRB. The findings of this research clearly demonstrate the readiness of IBIs in Aceh to play an important role in supporting the implementation of Shariah law comprehensively, especially in the economic and banking sectors. The general requirements for such action, which implements Islamic ethical values, has been fulfilled. Thus, the provincial government of Aceh should have the IBIs as partners and involve them in creating any regulations related to the sectors. 
For Islamic banking itself, the implementation of Islamic ethical culture must be strengthened to reflect what Islamic ethical values are so as to be most prominent. At the same time, the awareness of all employees in Islamic banks should also be increased. Thus, Islamic banks should take action to develop, maintain and enhance an Islamic ethical environment within the banks. For example, a code of ethics and ethical policies and procedures should reflect the Islamic ethical values and be actively enacted, rather than just being a status symbol within the banks. Consequently, an appropriate approach should be undertaken by the Islamic banks to provide a clear, concise and coherent vision about their commitment to enhance the IWE by individuals in these banks. This is important in eliminating suspicions among unconvinced critics who observe the IBIs from the outside.

\section{REFERENCES}

'Sharia Bank,' Otoritas Jasa Keuangan Indonesia, http://www.ojk.go.id/en/ sharia-bank.

Abbas Ali \& Mohammed Al-Shakhis, 'Managerial Beliefs About Work in Two Arab States,' Organization Studies, 10/2 (April 1989): 169-186.

Abbas Ali, 'Scaling an Islamic Work Ethic,' The Journal of Social Psychology, 128/5 (1988): 575-583.

Abbas J. Ali \& Ahmed A. Azim., 'Islamic Work Ethic and Organization in Development,' (Paper presented at the 23rd International Congress of Applied Psychology, Madrid, Spain, 17-22 July 1994).

Abbas J. Ali, 'The Islamic Work Ethic in Arabia,' Journal of Psychology, 126/5 (Sep. 1992): 507-519.

Abdus Sattar Abbasi, Ghulam Mustafa Mir, and Muzammil Hussain, 'Islamic Work Ethics: How They Affect Organizational Learning, Innovation and Performance,' Actual Problem of Economics, 12 (2012): 471-480.

Abdus Sattar Abbasi, KashifUr Rehman, and Amna Bibi, 'Islamic Work Ethics: How It Affcets Business Performance,' Actual Problem of Economics, 126/12 (2011): 312-322.

Abul Hassan, Abdelkader Chachi \& Salma Abdul Latiff, 'Islamic Marketing Ethics and Its Impact on Customer Satisfaction in the Islamic Banking Industry,' J.KAU: Islamic Econ, 21/1 (2008): 23-40.

Ainur Rahman, 'Menghapus Nila Setitik di Bank Syariah,' Majalah Stabilitas, http://www.stabilitas.co.id/view_articles.php?article_id=231\&article_ type $=0 \&$ article_category $=2$. 
Asyraf W. Dusuki, 'The Ideal of Islamic Banking: A Survey of Stakeholders' Perception,' Review of Islamic Economics, 11, no. special (2007): 29-52.

Azharsyah Ibrahim \& Nor 'Azzah Kamri, 'Measuring the Islamic Work Ethics: An Alternative Approach,' in Islamic Perspective on Management: Contemporary Issues, ed. Nor 'Azzah Kamri, Azian Madun \& Suhaili Sarif (Kuala Lumpur: YaPEIM Management Academy \& Dept. of Shariah and Management, University of Malaya, 2013), 135-163.

Bank Aceh, Annual Report 2012: Strategic Transformation, Building and Strengthening Foundation of Bank Business Growth (Banda Aceh: Bank Aceh Syariah, 2012).

Bank Muamalat Indonesia, Annual Report 2012: The Great Leap Forward (Jakarta: Bank Muamalat Indonesia, 2012).

BNI Syariah, Annual Report 2012: Reliable Banking Partner (Jakarta: BNI Syariah, 2012).

Darwish A. Yousef, 'Islamic Work Ethic: A Moderator between Organizational Commitment and Job Satisfaction in a Cross-Cultural Context,' Personnel Review, 30/2 (2001): 152-169.

Darwish A. Yousef, 'Organizational Commitment as a Mediator of the Relationship between Islamic Work Ethic and Attitudes toward Organizational Change,' Human Relations, 53/4 (2000): 513-537.

Husein Umar, Metode Penelitian untuk Skripsi dan Tesis Bisnis (Jakarta: Raja Grafindo Persada, 2007).

J Martin Bland \& Douglas G Altman, 'Statistics Notes: Measurement Error,' Bmj, 312/21 (1996): 1654.

Kamal Naser, Ahmad Jamal \& Khalid Al-Khatib, 'Islamic Banking: A Study of Customer Satisfaction and Preferences in Jordan,' International Journal of Bank Marketing, 17/3 (1999): 135-151.

Khaled M. K. Alhyasat, 'The Role of Islamic Work Ethics in Developing Organizational Citizenship Behavior at the Jordanian Press Foundations,' Journal of Islamic Marketing, 3/2 (2012): 139-154.

Khurram Zafar Awan \& Mehwish Akram, 'The Relationship between Islamic Work Ethics and Innovation Capability and Knowledge Sharing Plays Moderation Role,' International Journal of Economics and Management Sciences, 1/8 (2012): 34-48.

M. Adli Musa, 'Islamic Business Ethics \& Finance: An Exploratory Study of Islamic Banks in Malaysia' (Paper presented at the 8th International Conference on Islamic Economics, Doha, Qatar, 19-21 December 2011). 
Mehmet Asutay, 'The Socio-Ethical Failure in Islamic Banking and Finance,' (IIBI Lecturer Series, Institute of Islamic Banking and Insurance, London, 2011).

Mohammad Taqiuddin Mohamad, Joni Tamkin Borhan \& Ahmad Azam Sulaiman@Mohamad, 'Krisis Kewangan Global: Kestabilan dan Karakteristik Unik Perbankan Islam,' Shariah Journal, 22/1 (2014): 5786.

Muhammad Yousuf Khan Marri, Arshad Mahmood Sadozai, Hafiz Muhammad Fakhar Zaman, Muhammad Israr Yousufzai \& Muhammad I. Ramay, 'Measuring Islamic Work Ethics and Its Consequences on Organizational Commitment and Turnover Intention an Empirical Study at Public Sector of Pakistan,' International Journal of Management Sciences and Business Research, 2/2 (2013): 37-49.

Naresh Kumar \& Raduan Che Rose, 'Examining the Link between Islamic Work Ethic and Innovation Capability,' Journal of Management Development, 29/1 (2010): 79-93.

Nik Mu’tasim Ab. Rahman, Nordin Muhamad \& Abdullah Sanusi Othman. 'The Relationship between Islamic Work Ethics and Organizational Commitment: A Case Analysis,' Malaysian Management Review, 41/1 (2008): 79-89.

Nor 'Azzah Kamri, Siti Fairuz Ramlan \& Azharsyah Ibrahim, 'Qur'anic Work Ethics,' Journal of Usuluddin, 40 (July-December 2014): 135-172.

Otoritas Jasa Keuangan, Statistik Perbankan Syariah (Islamic Banking Statistic) August 2014 ed. (Jakarta: OJK, October 2014).

Sharifah Hayaati Ismail al-Qudsy, 'Values and Ethics Towards Quality Public Delivery System of Malaysia: An Islamic Perspective,' Shariah Journal, 15/2 (2007): 25-43.

\section{Statutes}

Bank of Indonesia's Circular Letter No. 15/063A/OPS dated 30 September 2013 on Goods and Services Procurement Implementation.

Indonesia Act of Islamic Banking No. 21/2008. 
Jurnal Syariah, Jil. 24, Bil. 1 (2016) 93-114 